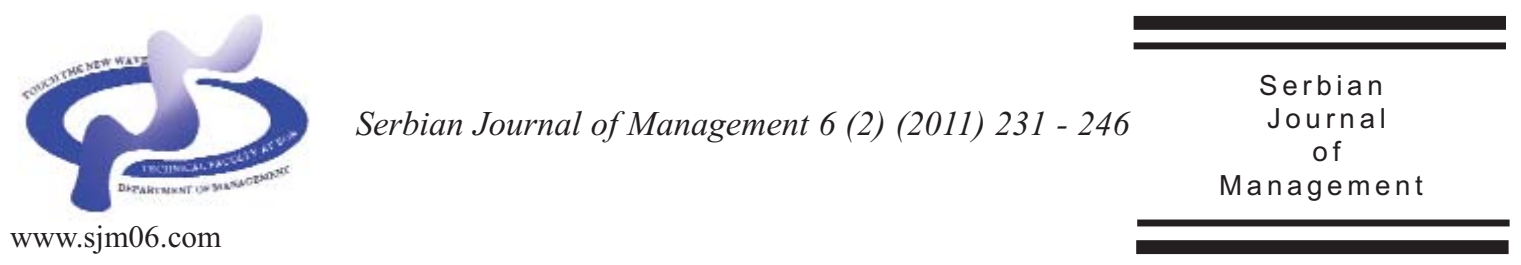

\title{
SUCCESSION PLANNING AND ORGANIZATIONAL SURVIVAL: EMPIRICAL STUDY ON NIGERIAN PRIVATE TERTIARY INSTITUTIONS
}

\author{
Osibanjo Omotayo Adewale*, Abiodun Joachim Abolaji and Obamiro John Kolade \\ Department of Business Studies, Covenant University, Ota Ogun State, Nigeria
}

(Received 11 June 2011; accepted 17 September 2011)

\begin{abstract}
Organizational survival has been argued to be a primary goal or objective every organization should have. This paper proposes a conceptual framework of succession planning consisting of six variables (talent retention, turnover rate, career development, supervisor' support, organizational conflicts and nepotism) and to explain the relationship among these variables regarding survival of organizations. The sample consists of three private tertiary institutions in Ogun-State, Southwest Nigeria. The results indicate that Talent retention, organizational conflict and nepotism positive and significantly correlated with organizational survival. On the other hand variables such as Turnover Rate, Career Development and Supervisor' Supervision) are insignificantly correlated with organizational survival. The results are supposed to inform the leadership (management) team with essential insight into the relationship among the study variables (independent and dependent).
\end{abstract}

Keywords: Succession Planning, Organizational Survival, Private Tertiary Institution, Nigeria

\section{INTRODUCTION}

Robbins and DeCenzo (2005) defined organization as "a systematic arrangement of people brought together to accomplish some specific purpose". In the words of Hitt (1988), organization is "the framework of responsibility, authority and duties through which the resources of an enterprise are brought together and coordinated for the achievement of set goals". As expected organizations strive for survival and continuity on one hand, which are paramount; on the other hand, manpower planning (Human Resource) is essential and seen as the total package in relation to the

\footnotetext{
* Corresponding author: koyepaul@yahoo.com
}

DOI: $10.5937 /$ sjm 1102231A 
quality and quantity of the workforce in organization.

Manpower Planning has been argued to be a broad-level concept that deals with the entire workforce, ensuring that the organizations have adequate and required sizeable number of workforce with the required skills and should be timely. Manpower Planning forecasts the requirements of workforce and plans for the acquisition, retention and effective utilization of employees, which ensure that the needs of company for people are met (Armstrong, 2006; Kingir and Mesci, 2010).

It is imperative to note that employees leave their jobs either voluntary (retirement or pursue new aspirations) or involuntary (relieve of appointment, death). Organizations are therefore, faced with vacancies in leadership or inadequacy or lack of competent and capable successor to fill the vacancies. Organizations are to act now and begin to plan for succession before top managers are ready for retirement (Korn, 2007). Charan, et al. (2001) argue that it is essential for organizations to train successors before the vacancies are created. Manpower planning is argued to be a straightforward and direct concept, which does not deal with individual or any particular employee (Ekamper, 1996). While on the other hand, Succession Planning is a sub-level approach regarding individual employees on an individual basis, should the incumbent vacate his position, which is uncertain and probably indefinite (Harter, 2008; Landeta, et al., 2009). However, it is therefore essential, for organizations to survive, there is need to plan for succession of older (outgoing) employees (Hazarika, 2009).

The purpose of this paper, therefore, is to raise a number of critical issues about the relationship between the practice of manpower planning and succession planning regarding organizational growth and survival, in addition, to suggest some important opinions for adequate manpower planning implementation in relation to organizational performance and in similar direction to recommend some areas for future research. However, as obtained in the literature, varieties of studies on succession planning have been conducted in developed nations particularly in industries (Amburgh, et al., 2010; Redmond, 2006; Singer, et al., 2004; Van, et al., 2010; Stefanovic et al., 2011). Essentially, very few of such studies have been conducted in developing economy like Nigeria, much less in private educational sector in which our study is designed to fill this gap in literature.

\section{REVIEW OF THE LITERATURE}

\subsection{Concept of Manpower Planning}

As obtained in the literature, several studies have argued asserting that the function of personnel in contemporary organizations is undergoing a radical transformation; departing from the era of personnel administration to a concept of comprehensive and integrative approach that focuses on the adequate utilization and development of human resources (Burack, \& Gutteridge, 1978; Fitzgerald, 1992; Bjornberg, 2002; Alphander, 1980). This new concept is referred to by several names such as human resource planning, manpower planning, human resource management, etc. This concept has been defined by different authors in various ways and the only conclusion is that manpower planning is referred to as the total package of the personnel-related activities (Burack, \& 
Gutteridge, 1978). Essentially, considerable misunderstanding and disagreement exists regarding the components of manpower planning and in addition, it is important to note that diversity also exists in organizations regarding the content of "manpower planning" programmes. There are a number of external pressures that motivate organizations to adopt a new model for manpower planning (Stybel, 1982). Enforcement of Equal Employment Opportunity (EEO) legislation has made many organizations to modify their employee management in areas such as recruitment, selection, compensation, performance appraisal and other related practices (Risher, \& Stopper, 2002; Pynes, 2004). It is evident that EEO legislation and manpower planning has made the bad situation worse, whereby newly hired and old employees are more concerned about work life quality and departing from the concept of employee who subordinates his personal life to the demands of the organization he works for. In the same direction, employees are becoming insistent that employers should have laudable career programmes, establish improved work climates, and above all their personal needs and aspirations should be factor into management decisions (Helton, \& Soubik, 2004). Similarly, Pension Reform Law also has significant implications on organization personnel policies and procedures. Distribution of age of the workforce and the educational level attainment of the population should also be taken into consideration by organizations regarding manpower planning (Fleischmann, 2000). However, it is often said that insufficient or unqualified workforce in organization is as serious as scarcity of raw materials in production. Similarly, it has been argued that investment in manpower is as equally important as in acquisition of plants, equipment and materials for organizational growth and survival (Walker, 1974; Butterfield, 2008). Some organizations were forced to reschedule their plans for expansion due to their inability to procure the needed human resources; while some companies experienced high manpower planning errors, poor product, lower level of efficiency and poor service quality simply because they failed to anticipate the basic manpower requirement for their organizations (Lengnick-hall, \& Lengnickhall, 1988).

\subsection{Manpower Planning Defined}

Manpower planning projects the human resources required by the management of an organization in order to achieve its strategic goals. In the word of Stybel (1982) Manpower planning is refers as "the identification of current and future job requirements, assessment of internal human resource capability in relation to those requirements, and institutionalization of management development/management succession framework". Bulla and Scott (1994) define manpower planning as "the process for ensuring that the human resource requirements of an organization are identified and plans are made for satisfying those requirements".

Generally, the major purpose of manpower planning is to match (human) resources to organizational needs in the shorter and longer terms requirements. It is also concerned with quantitative, qualitative and issues regarding the ways and manners in which persons are engaged and developed so as to meet or improve organizational efficiency and effectiveness. 
Sparrow (1992) argues further that "Human Resource Planning picks up the issues that are at the heart of the business, such as acquisition, decentralisation, empowerment, internationalisation or technology, and investigates their human resource management implications. HRP therefore requires a strategic approach to the recruitment, development, management and motivation of the people in the organisation, in the context of a pressing business issue. It is a systematic process of linking human resource practices with business demands in order to improve an organisation's abilities. It establishes the plans, courses of action and targets for the range of policies needed to enable the organisation to influence the management of its human resources".

\subsection{Succession planning Defined}

Taylor (2002) identifies three types of planning that aim at achieving practical goals and objectives of organisation. (1) Microplanning deals with forecasting supply and demand for specific groups. (2) Contingency planning covers the situation where possible scenarios are examined and the implications assessed before major decisions are taken. (3) Succession planning is a third type that focuses on manpower planning activity such as recruitment and development of employees in order to fill managerial and top positions. Collins (2009) defines succession planning as "a process that can provide seamless leadership transition across the organization". Strategic, systematic and deliberate effort to develop competencies in potential leaders through proposed learning experiences such as targeted rotations and educational training in order to fill high-level positions without favoritism (Tropiano, M., 2004).
In the words of Charan et al (2001) succession planning is perpetuating the enterprise by filling the pipeline with highperforming people to assure that every leadership level has an abundance of these performers to draw from, both now and in the future. From this perspective, succession planning is seen as management pipeline that accelerates management performance over a period of time. Charan' definition looks into the future and this probably influences Scharmer (2007) assertion that succession planning is co-creating, a transformational stage during which management explores the future. Succession planning is organized process comprising the identification and preparation of potential successor to assume new role (Garman \& Glawe, 2004). However, this definition is short and compact, but it is not futuristic and lack strength when compared with Charan's definition. The Journal for Quality and Participation (2005) reported that $67 \%$ of companies do not have a succession plan and $45 \%$ have no executive development plan in place and it was argued that the crisis could be alleviated by implementing succession training programmes (Khumalo, \& Harris, 2008).

\subsection{Succession Models}

\subsubsection{Relay Succession Planning Model}

Santorin (2004) came up with the first succession model, which is referred to as "Relay Succession Planning". In this model, He advocates that current $\mathrm{CEO}$ of an organization should pass the baton to a successor over a long period of time. The impact of companies practicing this model is being evaluated in Santorin's research compared with organizations do not have 
such plans in place. However, it was recorded that organizations that practice relay succession plans performed better because the successors were exposed to corporate challenges and were able to deal with such challenges in the pre-succession phase. Obviously, current CEO was able to pass the baton in real time and this would give the successor the opportunity to test the reins of leadership and at the time receive training. In similar direction, organizations that implemented relay succession model should perform better in the post-succession phase, because he been tried and tested, which implies that experience would be speaking for him. However, it is essential to note that not all organizations would hold the view that hiring internally is better, some organizations may prefer outsider in order to inject fresh ideas and vision thereby bringing positive change into the organization. It is evidence in Santorin's research that those organizations that had internal relay succession model had a higher return on investment over time (Santorin, 2004).

\subsubsection{Scharmer's Theory U Model}

Scharmer (2007) came up with the second succession model which is referred to as "Scharmer's Theory U Model". Scharmer argues that the Top Management Team should embrace and act in order to implement succession planning. In the first instance, this model views succession planning as beginning from the immediate future and supports a concept of a $U$ process of five movements that can make change possible (Scharmer, 2007). These movements are; (1) Co-initiating - in the words of Scharmer, at this stage, organization establishes a common purpose with all stakeholders about a future event. (2)
Co-sensing - is the second movement stage in which an organization sees the need at hand collectively across boundaries. Also, at the stage, new ideas and innovation occur through collective input. (3) The third stage is Presencing, whereby the leadership of organization begins to see the future they envisage (Scharmer, 2007). This futuristic plan establishes a foundation for change, thereby spurs an organization to an expected end. Further, at this stage, it is observed that the leadership let go off unresolved past issues and forges ahead to a more realistic future. (4) The fourth in this model is 'cocreating' - Scharmer (2007) argues that at this stage, leadership of organization explores the future and prototypes what the future might look like. He goes further to suggest that leadership should make succession planning a long-term concept rather than working on organizational immediate requirements. Kartz (2006) argues further that there is need to assess company' strategy and policy that highlight the required qualifications of the successor in order to have a sustainable and dynamic succession plan in place. (5) The Scharmer's fifth movement in Theory $U$ stage 'coevolving' can help an organization to embrace change and implement succession planning strategies in the context of an emerging future (Scharmer, 2007).

\section{ORGANIZATION SURVIVAL}

Organizational survival and growth are implicit organizational goals requiring the investment of energy and resources (Jones \& Bartlet, 2008). Organization that doesn't have survival as a primary objective or goal should have re-think (Gross, 1968). The goal of organizational survival underpins all other 
goals (Gross, 1968). Paying attention to this goal contributes to the satisfaction and execution of other organizational goals. Gross argued that the concept of survival is an unwritten law of every organization. This suggests that every organization should see survival as an absolute prerequisite for its serving any interest whatsoever (Gross, 1968). The concept of organizational life cycle is modelled from the pattern seen in living organisms (Bernstein, 1955). In opposite direction, organization is assessed in phases of growth and development rather than in chronological years. The phases are linked up in subtle and unpronounced manner, but it is essential noting that not every organization displays the features of each phase as it progresses.

Organizations attempt to maintain the existing state of affairs, but essentially the larger part of their efforts is tilted toward survival (Mindy, 1998). It therefore paramount to identify some certain threats to organizational survival classified into internal and external. Roddy (2004), sees mentoring as one of the variables of succession planning concept. Further, he argues that the effect of mentoring as a variable of succession planning on the organization depends largely on the mentoring skills of the mentors (Roddy, 2004) and the protégé should be given a conducive environment that compel him to remain in the organization (Amburgh, et al., 2010). However, this study goes further to evaluate some of the internal variables/components that drain from the organization the effort that should be directed to the achieving the company' goals with implementation of succession planning; such as high turnover rate (which cut across the managerial level; top, middle and lower); career development, supervisor' support, internal conflict, nepotism, talent retention etc.

All variables proposed for this study that affect HR planning and succession planning regarding organizational survival is depicted in Figure 1.

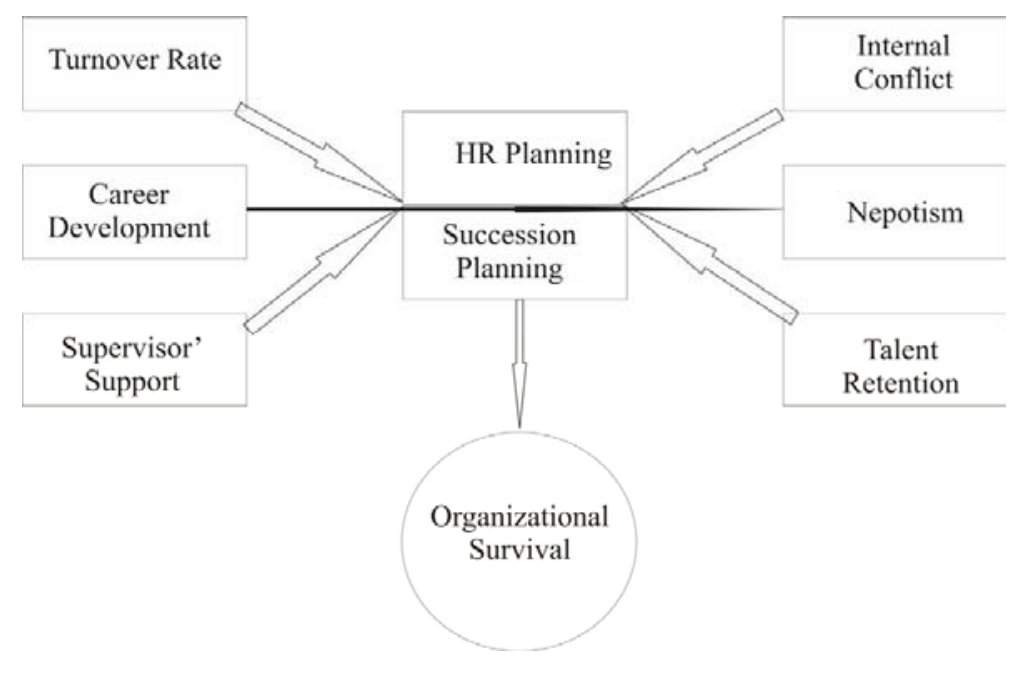

Figure 1. The Hypothesized model of the Interrelationships between succession planning variables and organizational survival (Source: Self-developed model) 
This study proposes the following in Nigeria began in 1948 with the hypotheses:

H1: There is relationship between employee turnover rate and organizational survival.

H2: There is relationship between career development and organizational survival.

H3: There is relationship between supervisor' support and organizational survival.

H4: There is relationship between internal organization conflict and organizational survival.

H5: There is relationship between nepotism and organizational survival.

H6: There is relationship between talent retention and organizational survival.

\section{PRIVATE TERTIARY INSTITUTIONS IN NIGERIA}

Tertiary institutions provide higher education in the educational industry. In Nigeria, there are one hundred and seventeen registered and accredited tertiary institutions, out of which forty five (45) are privately owned by organizational bodies such as religious groups, associations and individuals. The history of tertiary institution establishment of the Premier University (University of Ibadan) situated in Ibadan city, Oyo State-southwest Nigeria. Twelve (12) years after, the second university (University of Nigeria) was established in Nigeria, which was situated in Enugu State (Nsukka).

In the distribution Table 1., Federal and State Universities were thirty six (36) in number respectively, while private universities are forty five (45). Out of one hundred and seventeen universities population in Nigeria, private universities amount to $38 \%$ while the remaining $62 \%$ was shared equally between Federal and State Universities. Establishment of private university began in 1999 with three been universities licensed, however, the trend was slow till 2005, when there was an outburst and fifteen (15) private universities were given licence to provide tertiary education. Between of twelve (12) years (1999-2009), forty five private universities were licensed to provide tertiary education in Nigeria. Out which $47 \%$ are situated in the Southwest $\mathrm{N} \quad \mathrm{i} \quad \mathrm{g} \quad \mathrm{e} \quad \mathrm{r} \quad \mathrm{i} \quad \mathrm{a}$ (http://www.nuc.edu.ng/pages/universities.a $\mathrm{sp})$.

Table 1. Distribution of Tertiary Institutions in Nigeria

\begin{tabular}{|c|c|c|c|c|c|c|c|c|c|c|c|c|}
\hline & & \multicolumn{2}{|c|}{ University } & \multicolumn{2}{|c|}{ Federal } & State & \multicolumn{2}{|c|}{ Private } & Total & & & \\
\hline & & \multicolumn{2}{|c|}{ Number } & \multicolumn{2}{|c|}{36} & 36 & \multicolumn{2}{|c|}{45} & \multicolumn{2}{|l|}{117} & & \\
\hline & & \multicolumn{2}{|c|}{$\%$} & & & 31 & \multicolumn{2}{|c|}{38} & 100 & & & \\
\hline & \multicolumn{12}{|c|}{ Private Universities } \\
\hline Year & 1999 & 2001 & 200 & & 200 & & & 2006 & 2007 & 2009 & 2011 & Total \\
\hline Number & 3 & 1 & 3 & & 1 & & & 1 & 10 & 7 & 4 & 45 \\
\hline$\%$ & 7.0 & 2.0 & 7.1 & & 2.0 & & & 2.0 & 22.0 & 16.0 & 9.0 & 100.0 \\
\hline
\end{tabular}

2006 and 2011, additional eighteen (22) universities were also licensed. Within the period Source: http://www.nuc.edu.ng/pages/universities.asp (Retrieved March 7, 2011) 
5. REASONS FOR SUCCESSION PLANNING IN PRIVATE TERTIARY INSTITUTIONS IN NIGERIA

Manpower planning estimates the current and future demand of resources required in order to meet the organizational goals; while succession planning identifies key positions in the organization hierarchy and prepares successors to take over when the incumbent leaves. However, the major significant difference in these concepts is that Manpower planning is a macro-level approach, which deals with the entire workforce and does not get involved with individual or a specific position. On the other hand succession planning is a micro-level and long-term approach that deals with individual or specific positions regarding the eventuality of the incumbent leaving the organization. However, it is essential to note that the incumbent leaving the organization is futuristic and uncertain (Pynes, 2004; Hall, 1986; Haynes, \& Ghosh, 2008). Further, succession planning is a continuous process and subjective; the selection criteria for successors depend on organizational policies, competence, behavioral skills, and such like.

Inadequate of workforce leads to inability of the organization to meet its corporate goals, poor customer satisfaction, and lower profits. On the other hand, excess workforce leads to loss of productivity and excess wage bills. In similar direction, succession planning prevents disruption of organizational policies, goals and objectives. Succession planning arrests the negative effects of resignation or loss of talent in organizations. However, both manpower planning and succession planning concepts are essential to any organization, and it has been argued that organization that neglects either of these activities exposes itself to severe complications regarding human resource. (Nayab, 2010; Janjuha-Jivraj, \& Woods, 2002; Heffes, 2005; Smith, et al.,1992; Vosburgh, 2007).

It is evident from various studies that future leadership of organization is probably the most crucial aspect of its potential and continuing success and growth. It is therefore suggested that succession planning should be put in place in order to ensure that the organization has the potential successors with the right skills and attributes it requires to meet future business needs. However, Succession Planning is an emerging concept in developing nation like Nigeria not only in educational industry but in other industries as well and it is considered an essential tool in Human Resource Management (Gupta, \& Snyder, 2009; Greer, et al., 1989; Leggett, 2007; Mishra, \& El-Osta, 2008; Hall, 1986).

\section{METHODOLOGY OF RESEARCH}

The research design for this study requires a methodological approach which permits gathering of primary data on Manpower Planning and Succession Planning. The choice of Private Tertiary Institutions for the study was the high increase in number of the approved private universities and more importantly these universities are either owned by church or mosque and are therefore, apt to gain relevance, make profit and remain in business. The Primary data for the study was obtained through selfadministered questionnaire and personal interviews methods involving three private universities located in Ogun-State, Southwest Nigeria. These private universities were selected based on convenience, two are owned by the church 
organizations and one privately owned by an individual. Quota and random sampling techniques were adopted for this paper; a total of one hundred and fifty (150) questionnaires were equally administered among the selected three (3) private universities in the sample. Twenty-three of the administered copies of questionnaire were poorly filled and were not considered for final analysis. One hundred and twenty seven (127) copies of questionnaire were used for this study. The questionnaire utilized for the study is divided in two sections; the first section is to gather information on the respondents' characteristics like age, gender, marital status, work experience and educational level, while the second part seeks respondents opinion to manpower planning and succession planning with regard to organizational growth/survival, specifically: succession planning reduces employee turnover rate in organizations, succession planning helps in retaining company's talent, Supervisor's support plays an important role in succession planning. Respondents were to indicate their response on a seven-point Likert-type scale of 1(strongly disagree) to 7 (strongly agree).

\section{RESULTS OF INVESTIGATIONS}

The demographic makeup of the respondents is detailed in Table 2 .

The Table 2. displays the demographic of the respondent for this study. It is evident in the gender category that $55.1 \%$ respondents were male while $44.9 \%$ were female. Obviously the males dominate in the sample with little difference. All respondents had formal university education with 19\% BSc/MBA holders; with $26.8 \% \mathrm{PhD}$ while most of the respondents possess MSc/MBA (74\%). The marital status revealed that $29.9 \%$ of the respondents were single and $70.1 \%$ were married. There was no record of divorced, separated or engaged respondent. This goes further to suggest that respondents were either single or married. $40.2 \%$ of the

Table 2. Respondents Demography

\begin{tabular}{|c|c|c|c|c|c|}
\hline Gender & Male & \multicolumn{2}{|c|}{ Female } & \multirow{2}{*}{\multicolumn{2}{|c|}{$\frac{\text { Total }}{127}$}} \\
\hline & 70 & \multicolumn{2}{|c|}{57} & & \\
\hline \multirow[t]{2}{*}{ Age } & $18-25$ years & $26-35$ years & \multicolumn{2}{|c|}{$36-50$ years } & $\begin{array}{c}\text { Above } 50 \\
\text { years }\end{array}$ \\
\hline & $6.3 \%$ & $44.9 \%$ & \multicolumn{2}{|c|}{$39.4 \%$} & $12 \%$ \\
\hline \multirow[t]{2}{*}{ Educational Level } & $\mathrm{PhD}$ & \multicolumn{2}{|c|}{$\mathrm{MSc} / \mathrm{MBA}$} & & $\overline{\mathrm{BSc} / \mathrm{BA}}$ \\
\hline & $26.8 \%$ & \multicolumn{2}{|c|}{$74 \%$} & & $19 \%$ \\
\hline \multirow[t]{2}{*}{ Marital Status } & \multirow{2}{*}{$\frac{\text { Married }}{70.1 \%}$} & \multicolumn{2}{|c|}{ Single } & & eparated \\
\hline & & \multicolumn{2}{|c|}{$29.9 \%$} & & Nil \\
\hline \multirow[t]{2}{*}{ Work Experience } & $0-5$ years & \multicolumn{2}{|c|}{$\begin{array}{c}\text { Between } 6-10 \\
\text { years }\end{array}$} & & ears \& above \\
\hline & $22.0 \%$ & \multicolumn{2}{|c|}{$37.8 \%$} & & $40.2 \%$ \\
\hline
\end{tabular}

Source: Field Survey, 2011. 
respondents had been on the job above ten (10) years; followed by $37.8 \%$ of those respondents who had worked between 6-10years and $22.0 \%$ had worked between $0-5$ years.

Table 3. shows the correlations matrix of variables with the use of Pearson $r$ correlation coefficients between each pair of variables in this study. Obviously, in general there is low correlation among the study variables. However, there is high positive correlation between talent retention and organizational growth/survival $(\mathrm{r}=.768$; $\mathrm{p}<0.01$ ); high negative correlation between talent retention and turnover rate $(\mathrm{r}=-.583$; $\mathrm{p}<0.01)$; while medium correlation coefficient exists among organizational conflicts and career development $(r=.470$; $\mathrm{p}<0.01)$; career development and turnover rate $(\mathrm{r}=-3.66 ; \mathrm{p}<0.01)$; nepotism and career development $(\mathrm{r}=.387 ; \mathrm{p}<0.01)$ and also negative relationship exists between turnover rate and organizational growth $(\mathrm{r}=-.464$; $\mathrm{p}<0.01)$. The small significant that exists between organizational growth/survival and career development $(r=.266 ; p<0.01)$ could be attributed to some explanation in the human development which argues that some organizations are of the opinion that career planning might communicate to employees that their jobs are at risk. In similar direction employees may not present themselves for such programmes.

Table 4. reveals that 73 percent of the organizational survival/growth depend on the study variables such talent retention, turnover rate, career development and so on. In addition, it also reveals the model summary of the study variables which reveal that organization survival/growth is determined by their expectations and assessment of their impacts with private tertiary institutions.

\section{Table 3. Correlations Matrix of Variables}

\begin{tabular}{|l|l|r|r|r|r|r|r|r|r|r|}
\hline & & Mean & $\begin{array}{c}\text { Std. } \\
\text { Deviation }\end{array}$ & \multicolumn{1}{|c|}{1} & 2 & 3 & 4 & 5 & 6 & 7 \\
\hline 1 & Turnover Rate & 5.72 & 1.717 & 1 & & & & & & \\
\hline 2 & Career Development & 4.61 & 1.261 & $-.366(* *)$ & 1 & & & & & \\
\hline 3 & Supervisor' support & 5.21 & .752 & .009 & -.011 & 1 & & & & \\
\hline 4 & Organizational growth/survival & 4.80 & 1.564 & $-.464(* *)$ & $.266(* *)$ & $.178(*)$ & 1 & & & \\
\hline 5 & Organizational conflicts & 4.62 & .844 & -.138 & $.470(* *)$ & -.047 & -.045 & 1 & \\
\hline 6 & Nepotism & 4.83 & 1.809 & -.062 & $.387(* *)$ & $.191(*)$ & .139 & .123 & 1 & \\
\hline 7 & Talent Retention & 4.97 & 1.522 & $-.583(* *)$ & $.382(* *)$ & $.193(*)$ & $.768(* *)$ & $.324(* *)$ & -.042 & 1 \\
\hline
\end{tabular}

* Correlation is significant at the 0.05 level (2-tailed).

** Correlation is significant at the 0.01 level (2-tailed).

Table 4. Model summary of the study independent variables and the organization survival/growth

\begin{tabular}{|c|c|c|c|c|c|c|c|c|c|}
\hline \multirow[b]{2}{*}{ Model } & \multirow[b]{2}{*}{$\mathrm{R}$} & \multirow[b]{2}{*}{ R Square } & \multirow{2}{*}{$\begin{array}{l}\text { Adjust } \\
\text { ed R } \\
\text { Square }\end{array}$} & \multirow{2}{*}{$\begin{array}{l}\text { Std. Error } \\
\text { of the } \\
\text { Estimate }\end{array}$} & \multicolumn{5}{|c|}{ Change Statistics } \\
\hline & & & & & $\begin{array}{c}\text { R Square } \\
\text { Change }\end{array}$ & F Change & dfl & df2 & $\begin{array}{c}\text { Sig. F } \\
\text { Change }\end{array}$ \\
\hline 1 & $.859(\mathrm{a})$ & .739 & .726 & .819 & .739 & 56.536 & 6 & 120 & .000 \\
\hline
\end{tabular}

a Predictors: (Constant), Nepotism, Talent Retention, Supervisor' support, Organizational conflicts, Turnover Rate, Career Development

b Dependent Variable: Organizational growth/survival 
Table 5. shows that the observed differences in the study variables; nepotism, talent retention, turnover rate, career development, supervisor'support, organization conflicts regarding the organization survival/growth are significant with $\mathrm{F} 6,120=56.536$ and $\mathrm{P}<0.05$.

The results of multivariate regression on relationship between manpower planning and succession planning regarding organizational growth/survival is illustrated in table 6.

The model in Table 6. explains the relationship between manpower planning and succession planning regarding organizational survival with respect to talent retention, Nepotism, Supervisor' support, Organizational conflicts, Turnover Rate, Career Development. Comparing the contribution of each independent variable; therefore we will use the beta values in the
Beta column. In this model the largest beta coefficient is .939, which is for Talent Retention. This variable makes the strongest unique contribution to explaining the dependent variable (organizational survival), when the variance explained by all other variables in the model is controlled for. The Beta value for organizational conflict is slightly lower (-.380), indicating that it made less of a contribution. Looking at the sig. column, variables $1,5 \& 6$ (Talent Retention, Organizational Conflict and Nepotism) have significant contributions to our prediction that organizational survival depend on these independent variables. On the hand, variables 2, 3 \& 4 (Turnover Rate, Career Development and Supervisor' Supervision) do not make any significance unique contribution to the prediction of our dependent variable (organizational survival).

Table 5. Analysis of variance of the study independent variables and organization survival/growth - ANOVA

\begin{tabular}{|l|l|r|r|r|r|c|}
\hline \multicolumn{2}{|l|}{ Model } & $\begin{array}{c}\text { Sum of } \\
\text { Squares }\end{array}$ & \multicolumn{1}{c|}{ df } & $\begin{array}{c}\text { Mean } \\
\text { Square }\end{array}$ & F & Sig. \\
\hline 1 & Regression & 227.573 & 6 & 37.929 & 56.536 & $.000^{\mathrm{a}}$ \\
\hline & Residual & 80.506 & 120 & .671 & & \\
\hline & Total & 308.079 & 126 & & & \\
\hline
\end{tabular}

a Predictors: (Constant), Nepotism, Talent Retention, Supervisor' support, Organizational conflicts, Turnover Rate, Career Development b Dependent Variable: Organizational growth/survival

Table 6. Multivariate regression on relationship between manpower planning and succession planning regarding organizational growth/survival

\begin{tabular}{|c|c|c|c|c|c|c|c|c|c|c|c|c|c|}
\hline \multirow{2}{*}{\multicolumn{2}{|c|}{ Model }} & \multicolumn{2}{|c|}{$\begin{array}{c}\text { Unstandardized } \\
\text { Coefficients }\end{array}$} & \multirow{2}{*}{$\begin{array}{c}\begin{array}{c}\text { Standardized } \\
\text { Coefficients }\end{array} \\
\text { Beta } \\
\end{array}$} & \multirow{2}{*}{$\mathrm{t}$} & \multirow{2}{*}{ Sig. } & \multicolumn{2}{|c|}{$\begin{array}{c}95 \% \text { Confidence } \\
\text { Interval for B }\end{array}$} & \multicolumn{3}{|c|}{ Correlations } & \multicolumn{2}{|c|}{$\begin{array}{c}\text { Collinearity } \\
\text { Statistics }\end{array}$} \\
\hline & & \multirow{2}{*}{$\frac{\mathrm{B}}{2.665}$} & \multirow{2}{*}{$\begin{array}{l}\begin{array}{l}\text { Std. } \\
\text { Error }\end{array} \\
.782\end{array}$} & & & & Lower & Upper & Zero- & Partial & Part & Tolerance & VIF \\
\hline 1 & (Constant) & & & & 3.410 & .001 & 1.118 & 4.212 & & & & & \\
\hline & 1 & .965 & .067 & 939 & 14.382 & .000 & .832 & 1.098 & .768 & .796 & .671 & .510 & 1.959 \\
\hline & 2 & .047 & .055 & .051 & .855 & .394 & -.062 & .155 & -.464 & .078 & .040 & .603 & 1.660 \\
\hline & 3 & .015 & .077 & .012 & .196 & .845 & -.138 & .168 & .266 & .018 & .009 & .559 & 1.789 \\
\hline & 4 & -.140 & .105 & -.067 & -1.334 & .185 & -.348 & .068 & .178 & -.121 & -.062 & .853 & 1.172 \\
\hline & 5 & -.704 & .101 & -.380 & -6.945 & .000 & -.905 & -.503 & -.045 & -.535 & -.324 & .726 & 1.377 \\
\hline & 6 & .205 & .047 & .237 & 4.386 & .000 & .113 & .298 & .139 & .372 & .205 & .744 & 1.344 \\
\hline
\end{tabular}

a Dependent Variable: Organizational growth/survival 


\section{DISCUSSION}

The results of this study show that independent variable (talent retention) as a mediator variable in succession planning concept contributes a significant effect in survival and growth of organizations. Talent management has been argued to be a variable under succession (Daily, et al., 2000), human resource development (Bartlett, et al., 2002), and organizational learning (Adler \& Bartholomew, 1992). Irrespective of the terminology, it is paramount to acknowledge the value of talent retention as a competitive weapon for organizational survival.

The results demonstrate that organizational conflict made less of a contribution to the dependent variable. As obtained in the literature organizations are referred to as living open systems that comprises of various interacting department jointly carrying out a specific task within a structure of scarce resources (Katz, \& Kahn, 1976, Boulding, 1957). Essentially, conflicts would surely manifest in organizations regarding distribution of resources, fundamental conflict about the very structure of their organization and the basic nature of their interaction (Aubert, 1963, Deutsch, 1969). However, when there are unresolved conflicts among the parties, it destroys and derails organizational focus (Deutsch, 1969).

\section{CONCLUSION}

One of the basic and fundamental goals of any organization and firm is growth/survival. Therefore, it is imperative to employ some strategic human development concepts in order to achieve these organizational goals, bearing in mind that human resource plays a vital role. Despite the fact that survival is a major goal, we opine that the fundamental problem is that some organizations perceive succession planning as a huge task and could not get started.

Three main independent variables of succession planning concept of the human resource planning namely; Talent Retention, Organizational Conflict and Nepotism play a vital role to enhance the organizational survival/growth in the private tertiary institutions in Nigeria. The high positive relationship between these independent variables and depend variable provides a wisdom avenue for the management of private tertiary institutions in Nigeria to make their institutions relevant and remain in the industry and also motivate the employees to be more effective and efficient. Further, the high negative correlation that exists between variables talent retention and turnover rate suggests that there is need to properly manage talented employees in order to reduce the turnover rate. In other words, talent management can reduce the turnover rate in organizations.

This study concludes that unhealthy organizational conflicts among the employees and employers affect the survival/growth of organizations. Though, conflict has been argued to be a natural phenomenon with positive or negative impacts (Sheppard, 1984). It has been argued that conflict cannot be resolved but can be managed by the use of organizational structures, processes and methods, which will make conflicting groups to resolve their differences amicably (Sheppard, 1992). 


\title{
ПЛАНИРАЊЕ УСПЕХА И ОПСТАНАК ОРГАНИЗАЦИЈА: ЕМПИРИЈСКА СТУДИЈЕ НИГЕРИЈСКИХ ПРИВАТНИХ ТЕРЦИЈАЛНИХ ИНСТИТУЦИЈА
}

\author{
Osibanjo Omotayo Adewale*, Abiodun Joachim Abolaji and Obamiro John Kolade \\ Department of Business Studies, Covenant University, Ota Ogun State, Nigeria
}

\begin{abstract}
Извод
Опстанак организације се често сматра примарним циљем или објектом сваке организације. Овај рад предлаже концептуални оквир планирања успеха који се састоји од шест промењивих (задржавање најталентованијих радника, обрт капитала, развој каријере, подршка надређених, управљање конфликтима и непотизам), као и односе међу овим промењивим у циљу опстанка организације.Узорак се састојао од три приватне терцијалне институције у републици Огун, југозападна Нигерија. Резултати индицирају да су задрђавање талената, управљање конфликтима и непотизам позитивно и значајно у корелацији са опстанком организације. С друге стране, промењибе као што су обрт капитала, развој каријере и подршка надређених нису у довољној корелацији са опстанком организације. Ови резултати треба да информишу лидере (менаџмент) ових институција о односу међу проучаваним промењивим.
\end{abstract}

Кључне речи: Планирање успеха, Опстанак организација, Приватне терцијалне институције, Нигерија

\section{References}

Adler, N.J., \& Bartholomew, S. (1992). Academic and professional communities of discourse: Generating knowledge on transnational human resource management. Journal of International Business Studies, 23: 551-569.

Alphander, G.G. (1980). Human Resource Planning in U.S. Corporations. California Management Review, 22(3): 24 32.

Amburgh, J.V., Surratt C.K., Green, J.S., Gallucci, R.M., Colbert, J., Zatopek, S.L., \& Blouin, R.A. (2010). Succession Planning in US Pharmacy Schools. American Journal of Pharmaceutical Education, 74 (5): 86.
Aubert, V. (1963). Competition and Dissensus. Journal of Conflict Resolution, 7 , 26-42.

Armstrong, M. (2006) A Handbook of Human Resource Management Practice, Kogan Page, London (6), pp. 363-87.

Bartlett, K.R., Lawler, J.J., Bae, J., Chen, S., \& Wan, D. (2002). Differences in international human resource development among indigenous firms and multinational affiliates in East and South Asia. Human Resource Development Quarterly, 13: 383-405.

Bernstein, M. (1955). Regulating Business by Independent Commission (Princeton, N.J.: Princeton University Press). Bjornberg, L., (2002). Training and 
Development: Best Practices. Public Personnel Management. 31(4): 507-516.

Boulding, K.E. (1957). Organizations and Conflict, Journal of Conflict Resolution, 1(2), 122-134.

Bulla, D.N., \& Scott, P.M. (1994) Manpower requirements forecasting: a case example, in Human Resource Forecasting and Modelling, ed D Ward, T P Bechet and R Tripp, The Human Resource Planning Society, New York.

Burack, E.H., \& Gutteridge, T.G. (1978). Institutional Manpower Planning: Rhetoric Versus Reality. California Management Review, XX (3), 13 -22.

Butterfield, B. (2008). Talent Management: Emphasis on Action. CUPAHR Journal, 59(1): 34-38.

Charan, R., Drotter, S., \& Noel, J. (2001). The Leadership Pipeline: How to Build the Leadership Powered Company. San Francisco, GA: Jossey-Bass (owned by John Wiley \& Sons, Inc.)

Daily, C., Certo, T., \& Dalton, D. (2000). International experience in the executive suite: The path to prosperity? Strategic Management Journal, 21: 515-523.

Deutsch, M. (1969). Conflicts: Productive and Destructive. Journal of Social Issues, 25(1): 7-42.

Ekamper, P. (1996). Future AgeConscious Manpower Planning in the Netherlands. International Journal of Manpower, 18: 232-247.

Fleischmann, S.T. (2000). Succession Management for the entire Organization. Employment Relations Today (Wiley). 27(2): 53-62.

Fitzgerald, W. (1992). Training Versus Development. Training and Development Journal, 5:81-84.

Garman, A.N., Glawe, J. (2004). Succession Planning. Consulting Psychology
Journal: Practice \& Research, 56(2), 119128.

Gupta, M., \& Snyder, D. (2009). Comparing TOC with MRP and JIT: A Literature Review. International Journal of Production Research, 47(13): 3705-3739.

Greer, C.R., Jackson, D.L., \& Fiorito, J. (1989). Adapting Human Resource Planning in a Changing Business Environment. Human Resource Management, 28(1): 105123.

Gross, B. (1968). Organizations and Their Managing. New York: The Free Press, 454.

Hall, D.T. (1986). Dilemmas in Linking Succession Planning to Individual Executive Learning. Human Resource Management, 25(2): 235-265.

Harter, L. (2008). Succession Planning Part 11: Business Succession is a Team Sport. Journal of Practical Estate Planning, October - November, 2008.

Haynes, R.K., \& Ghosh, R. (2008). Mentoring and Succession Management: An Evaluative Approach to the Strategic Collaboration Model. Review of Business, 28(2) : 3-12.

Hazarika, A. (2009). Building the Pipeline: Leadership Succession is a Key Challenge. Leadership in Action. 29(4):8-12.

Heffes, E.N. (2005). Dramatic Workforce Trends Require Planning Now. Financial Executive, 21(6): 18-21.

Helton, K.A. \& Soubik, J.A. (2004). Case Study: Pennsylvania's Changing Workforce: Planning Today with Tomorrow's vision. Public Personnel Management, 33(4): 459473.

Hitt, M.A. (1988). The Measuring of Organization Effectiveness: Multiple Domains and Constituencies. Management International Review, 28(2): 28-40.

Janjuha-Jivraj, S., \& Woods, A. (2002). The Art of 'Good Conversations': A Strategy 
to Negotiate Succession within South Asian Family firms. Strategic Change, 11(8): 425434.

Jones and Bartlett Publishers Acquires Tarascon Publishing, Inc.". Reuters. 2008$\begin{array}{llllll}0 & 6 & - & 0 & 2\end{array}$. http://www.reuters.com/article/pressRelease/ idUS160467+02-Jun-2008+BW20080602. Retrieved March 8, 2011.

Kartz, J.P. (2006). CEO Succession: A Window on How Boards can get it Right when Choosing a New Chief Executive. Academy of Management Executive, 14(2): 130-131.

Katz, D. \& Kahn, R.L. (1976). The Social Psychology of Organizations (2nd ed.; New York: Wiley.

Kingir, S., Mesci, M. (2010). factors that affect hotel employees motivation, the case of Bodrum. Serbian Journal of Management, 5 (1): 59 - 76.

Korn, D.J. (2007). Securing Succession Success. Journal of Accountancy, 204(6): 3437.

Khumalo, F., \& Harris, M. (2008). Top Level Management Succession Plan Strategies. International Journal of Business Strategy, 8(3): 170-178.

Landeta, J., Barrutia, J., \& Hoyos, J. (2009). Management Turnover Expectations: A Variable to Explain Company Readiness to Engage in Continuous Management Training. International Journal of Human Resource Management, 20(1): 164-185.

Leggett, C. (2007). From Industrial Relations to Manpower Planning: The Transformations of Singapore's Industrial Relations. International Journal of Human Resource Management, 18(4): 642-664.

Lengnick-hall, C.A., \& Lengnick-hall, M. L. (1988). Strategic Human Resources Management: A Review of the Literature and a Proposed Typology. Academy of
Management Review, 13(3): 454-470.

Mindy, W.T. (1998). Paradigm Lost, Human Resource Executive (July 1998): 52.

Mishra, A., \& El-Osta, H. (2008). Effect of Agricultural Policy on Succession decisions of Farm Households. Review of Economics of the Household, 6(3): 285-307.

Nayab, N. (2010). What is the difference between Human Resource Planning and Succession Planning? Retrieved on March 3, 2011. Project Management Newsletter. http://www.brighthub.com/office/projectmanagement/articles/79865.aspx

Pynes, J.E. (2004). The Implementation of Workforce and Succession Planning in the Public Sector. Public Personnel Managment, 33(4): 389-404 .

Redmond, R.W. (2006). Leadership Succession Planning. An evidence based approach for manning the future. Journal Nurs Admin, 36(6): 292-297.

Risher, H., \& Stopper, W.G. (2002). Current Practices. Human Resource Planning, 25(1): 5-11.

Robbins, S.P., \& DeCenzo, D. A. (2005). Fundamental of Management. Prentice-Hall. Roddy, N. (2004). Leadership Capacity Building a Model: Developing tomorrow's leadership in science and technology - an example of Succession Planning and Management. Pub Pers Management. 33(4): 487-496.

Santorin, J.C. (2004). Passing the Baton. Academy of Management Executive, 18(4): 157-159.

Scharmer, C.O. (2007). Theory U: Leading the Future at it Emerges. Cambridge, MA: The Society for Organizational Learning, Inc.

Sheppard, B.H. (1984). Third Party conflict intervention: A Procedural Framework. Research in Organizational Behaviour, 6: 141-190. 
Sheppard, B.H. (1992). Conflict Research

as Schizophrenia: The Many Faces of Organisational Conflict. Journal of Organisational Behaviour, 13: 325-334.

Singer, P., Goodrich, J., Goldberg, L., (2004). Your Library's Future: when Leaders leave, Succession Planning can smooth transitions. Libr Journal. 129(17):38-40.

Smith, B.J., Boroski, J.W., \& Davis, G.E. (1992). Human Resource Planning. Human Resource Management, 31(1/2): 81-93.

Sparrow, P. (1992). Human resource planning at Engindorf plc. In: Winstanley, D., Woodall, J. (eds). Case Studies in Personnel. IPD; pp. 252-259.

Stefanovic, I., Rankovic, Lj., Prokic, S. (2011).Entrepreneurs motivational factors: empirical evidence from Serbia. Serbian Journal of Management, 6(1): 73-83.

Stybel, L.J. (1982). Linking Strategic Planning and Management Manpower Planning. California Management Review, 25(1): 48-56.

Taylor, S. (2002) People Resourcing, CIPD.

Van, A.J., Surratt, C.K., Green, J.S., Gallucci, R.M., Colbert, J., Zatopek, S.L., \& Blouin, R. A. (2010). Succession Planning in US Pharmacy Schools. American Journal of Pharmaceutical Education, 74(5): 1-7.

Vosburgh, R.M. (2007). The Evolution of HR: Developing HR as an Internal Consulting Organization. Human Resource Planning, 30(3): 11-23.

Walker, J.W. (1974). Evaluating The Practical Effectiveness of Human Resource Planning Applications. Human Resource Management, 74(13):19-27. 